SAŠA PETAR, Ph.D.

E-mail: sasa@sasapetar.com

Status Prosper d.o.o.

Šamačka 41, HR-10000 Zagreb, Croatia

IVONA BAJOR, B.Eng.

E-mail: ivona.bajor@fpz.hr

SINIŠA RADULOVIĆ, B.Eng.

E-mail: sinisa.radulovic@fpz.hr

University of Zagreb,

Faculty of Transport and Traffic Sciences

Vukelićeva 4, HR-10000 Zagreb, Croatia
Preliminary Communication Transport Logistics

Accepted: Oct. 26, 2009

Approved: Dec. 21, 2010

\title{
TECHNOLOGY TRANSFER AND LOGISTICS-DISTRIBUTION CENTRES
}

\begin{abstract}
The capital and technology transfer into a certain region leads also to increased demands for logistic services. The transition to the logistic delivery organisation is very important under the conditions of accelerated technological development, in particular in the field of telecommunications and informatics, which enabled the advent of successful companies having a single employee. Owing to the mentioned technologies these companies get networked with similar companies, thus being able to solve all their needs by outsourcing the services or products of other networked companies.

Higher speed and greater flexibility of operation of such companies has brought the following challenge: larger number of small companies has created a larger number of small orders that have to be delivered within the same unit of time. The logistics and distribution centres can represent a solution which maintains the speed and efficiency, and avoids costs of congestions and delays.
\end{abstract}

\section{KEY WORDS}

capital transfer, technology transfer, logistics and distribution centres, optimisation

\section{INTRODUCTION}

The Croatian economy is similar to the economies of other countries in transition, where the increase in the number of small and medium-scale companies as consequence of the return of the institution of private ownership as well as of recession that has affected "public" companies and the resulting notices, caused greater competition on the market and a change in the structure of the economic system. The problems faced by the owners of the new companies included: war and instability of the political (and thus also economic) situation; high inflation and devaluation of the nation- al currency; lack of financial means for investments, including even simple reproduction; reduction of the domestic market and facing stronger and more experienced competition on the foreign market; difficulties in changing old business habits by the majority of the employees; lack of medium management who would handle the management and operative realization of the tasks and the lack of organized market forms for technology and innovation transfer.

The problem of the business premises location is part of the development plans of every company in the business world. The logic of profit imposes moving to a location with a lease that is affordable or changing the type of business in order to attract new customers.

The world technological revolution offers today a wide selection of technical aids for successful operation on a small space, in order to ensure high quality and low, competitive price on the market. High competition on the premises market requires more flexible and efficient municipal boards, so that, knowing the trends of modern business operation, they would successfully organize the city and provide the investors a product whose competitive advantages can improve their business results.

Foreign entrepreneurs and politicians have often commented that they are interested in investing in Croatia, and in their opinion Croatia is a prospective country for the development, investments and business. These claims flatter the ear, but they do not fill up the stomach. No doubt, the war has had its impact on the restraint of foreign investors regarding Croatia, but the structure of the Croatian economy indicates that it is not only the war that is to blame for the slow opening up of Croatia towards the world capital.

For instance, it is often emphasised that the main strategic orientations of the economic development in 
Croatia and her comparative advantages are her traffic position, tourism and agriculture. However, it seems that one tends to forget that the war imposed a redirection of the traffic routes in this part of Europe, and that there is no country in Europe without a tendency to expand its tourism and without any agricultural orientation. These considerations have their origin much more in the interest-based concept of a closed market, in which the owners, on the basis of their possibilities and preferences, determine what somebody will do, rather than advocating open market behaviour. Regarding micro-economy, a company that starts from what they can produce, and not from what the market demands has no strong competitive ability on the market. And the capital is on the market.

Commerce, agriculture and fishery, traffic and connections as well as the catering trade and tourism all together accounted for $39.9 \%$ in the total GDP, which is less than the share of industry which is the basis of the society development and not found on the list of comparative advantages of Croatia. The world investments have turned today to high-tech industry, highly developed technologies and industry branches that are based on new technologies, and the data that 13.4\% of the Croatian GDP still comes from agriculture and fishery indicates the low-urbanized developing country that has only just arrived at the doors of the world investment boost in industry.

Croatia is today involved in the process of political and economic reforms in the ex socialist countries of Central and Eastern Europe whose market proclaims attractive 430 million potential customers, with about $15 \%$ of the world gross domestic product, and incomes much lower than the ones in the developed countries, but similarly "hungry" for the higher living standard and consumption.

\section{TECHNOLOGY TRANSFER AND INFRASTRUCTURE DEVELOPMENT}

Two concurrent processes have started to develop fast. The companies that intend to do business in the ex-socialist countries have faced the question of which countries to invest into and which "inflow" method to select. On the other hand, the governments of countries, potential candidates for foreign investments are trying to make their countries as attractive as possible, since the arrival of foreign companies bringing along private and bank capital, special business knowledge and experiences is one of the key factors of the transformations of the socialist into the market economies. Croatia is participating in this process.

The development of economy, especially in the developing countries is not possible without having connections with the developed countries and therefore Croatia is oriented to economic integrations that would enable faster development. In the process it is necessary to realize legal, social and economic preconditions that would attract the investors.

The success of the economic transition process in the countries of Central and Eastern Europe, including Croatia, will depend on the financial stabilisation, knowledge and technology transfer, inflow of foreign private capital and on the access to the market of the developed countries.

Investing into infrastructure facilities is important for the overall economic development of a country, but they cannot be subject to international exchange, since international trade cannot settle the imbalance between supply and demand of infrastructural facilities on the domestic market. The economic infrastructure facilities are always capital intensive (with capital in the developing countries being an expensive resource), of high value and long acquisition period of investment. Once constructed, as a rule, they cannot be used for other purposes ${ }^{1}$, so that in case of demand decline these are failed investments, and thus not interesting for the private capital.

However, investing into the existing economic branches of the developing countries usually serves to restructure the companies whose production is based on old technologies and to cover their business losses. These investments do not provide economic development of the developing countries over the long run, since they have no influence on the structural changes. The inflow of the private foreign capital, transfer of new technologies, business knowledge and experiences, that allow integration into the world financial and commercial flows, offer the developing countries the possibility of economic transition and reduction of differences regarding the developed countries.

Because of the war Croatia had been ranked until 1995 among countries of high investment risks, which put off the potential investors, and also raised (due to multiple insurances) the price of capital of those investors who "tested" the Croatian market with minor investments.

Apart from war activities, the Croatian economy was then burdened by low share of the realized domestic product of the private sector in the overall domestic product, only five per cent (at the same time in Poland this share was about 50\% and in Hungary $35 \%)$, whereas the displaced persons and refugees were granted one fifth (25\%) of this very domestic product.

Following 1995 legal preconditions were realized for greater inflow of the foreign capital, but an integral stimulating environment is still slow in development. The understanding of the meaning of environment in international business operation is to realize the advantage over the competitors. Since companies cannot change the social and economic environment of a country (economic, social and political, and cultural 


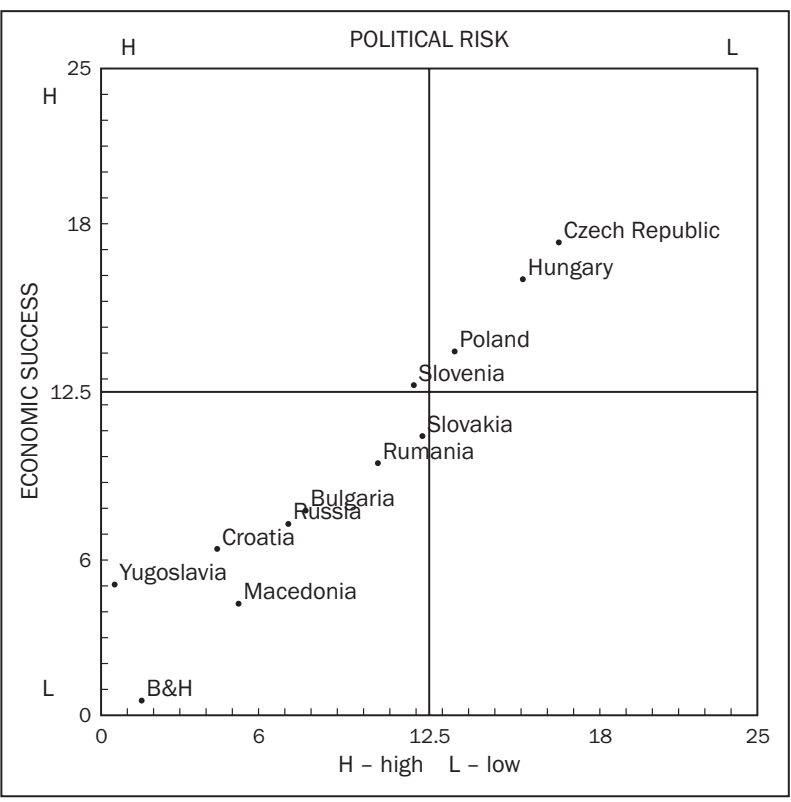

Figure 1 - Position of Croatia on the relation chart of political risk and economic success

Source: B. Crnjak-Karanović, Utjecaj okružja na interes i ulaz stranih firmi i kapitala u Hrvatsku, (Influence of environment on the interest and entry of foreign companies and inflow of capital into Croatia), Ekonomski pregled 9-10/1994, p. 671

conditions, natural resources and geographic characteristics, education level and qualification of professionals, and technology development level) they will make an attempt to locate themselves in an environment that suits them best.

\section{INFRASTRUCTURE PRECONDITIONS OF CAPITAL TRANSFER}

Fulfilling the social conditions (existence of infrastructure, qualified labour, connections to foreign technological achievements, etc.) positioning of foreign enterprises may be expected today in Croatia, mainly in the western part of the country (Zagreb, Rijeka, Varaždin) which is economically also the most developed part. Attracting foreign capital into other parts of Croatia will depend on the stimulating level for investments into certain economic branches or even regions.

The capital transfer into a certain region leads also to urban development since new enterprises need qualified labour. In order to achieve a more uniform development of Croatia, mitigating the pressure on Zagreb and its surroundings, the stimulating measures of the Croatian government in investing into eastern and southern regions of Croatia are imperative. The construction of capital infrastructure facilities (ZagrebRijeka-Split highway, all the way to Dubrovnik, ZagrebVaraždin highway, new power plants, etc.) opens up business premises and production plants (e.g. Du- gopolje near Split) and improved cargo flows. These are obligatory pre-conditions for the inflow of foreign investments, and only after these have been received structural changes in the Croatian economy can be expected. Besides, the presence and activities of foreign companies and their projects are the safest guarantee for receiving financial support from international financial institutions.

However, to attract enterprises that are developing high technologies (and do not require big infrastructure facilities for their activities) there are preconditions (higher education institutions, research space and laboratories, qualified professionals, informatics basis, developed telecommunications network) that do not require high investments into additional capitalization, and can provide good conditions to potential investors. With their activation, along with Croatian government stimulating measures, the time until the finalization of capital investments would be effectively used.

The transfer of capital and technology which is occurring intensively on the world market requires better and less expensive labour, premises which can accommodate new plants, environmentally friendly technologies and technologies that consume less energy and favourable government tax policy. Therefore, the recent five years have marked an increase in the production workers in South Korea, Taiwan, Singapore, Malaysia, Thailand and Indonesia, and a decrease in the number of workers in production companies in the USA, France, Great Britain, Germany, Italy and Canada.

Modern technology transfer is performed through direct investments, i.e. by acquiring full or majority ownership of the company - receiver of the technology, but also with bilateral or multilateral inter-government agreements, within which various possibilities for the technological knowledge transfer are established.

In the phase of integration with the European Union, Croatia has found itself in a special situation. Owing to an extremely favourable geographic position in the region, and a number of other factors, Croatia represents today an ideal logistic destination which is the catchment area both for the eastern and for the western neighbours. Determining all the comparative advantages of Croatia and providing entrepreneurs from the region with good and justified reasons for investing precisely in Croatia is a topic for some dozens of detailed scientific research projects.

Then we could compare the current position of the Republic of Croatia as a logistic centre with the neighbouring countries and define what should be undertaken to really orient Croatia into that direction, thus improving its export position through the logistic centres. 


\section{LOGISTICS IN TECHNOLOGICAL PARKS}

How does such a change look in practice? In 1994 in Zagreb and in 2002 in Bjelovar, the technological and business parks were established, having the function of constructing and managing the business zones, construction and management of free zones, management of entrepreneurial incubators, promotion of domestic and foreign investments and development of human resources. Their objectives and tasks include: continuous investments into development projects, improvement of investments and entrepreneurial climate, education of personnel, creation of workplaces, investments inflow, increase of export, improvement of technology and sustainable development in compliance with the development strategy of Croatia ${ }^{2}$.

Near Zagreb, along the Zagreb-Ljubljana highway, in close vicinity to the Sveta Nedelja interchange (southern side), five kilometres from the Slovenian border, the Business Park (Poslovni park) Zagreb was built in 2007, the first logistics and warehousing centre in Croatia.

The Business Park covers an area of $90,000 \mathrm{~m}^{2}$, and the facilities occupy $57,000 \mathrm{~m}^{2}$. The British company Macando invested 75 million euro in the construction and equipment of the Business Park Zagreb ${ }^{3}$. The Business Park is located along the Zagreb by-pass and connected by a highway with Western Europe, and in close vicinity to the planned Zagreb-Samobor railway line that is planned as connection to the cargo railway station in 2012. The logistics centre directly employs up to 700 people, and with the increase among suppliers and local companies, this number of new workplaces will grow.

Opening of such centres could change the image and habits of logistic process movements of cargo deliveries from producers to customers. Instead of ordinary movements, explained in Figure 2, in which the costs are high, and time utilisation low, the logistics and distribution business centres may influence to a large extent the efficiency of their operation, as well

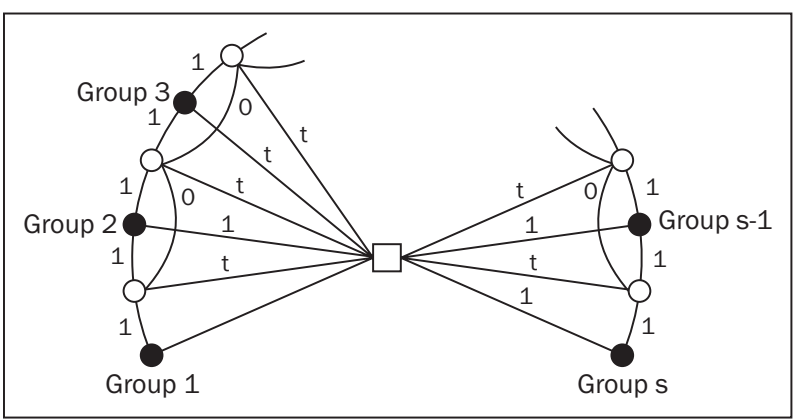

Figure 2 - Logistics-distribution network without logistics-distribution centres

Source: Simchi-Levi, D., Chen X. And Bramel J., The Logic of Logistics, p. 219 as of companies that they serve by transferring to the logistics delivery organization, presented in Figure 3.

Transition to logistics delivery organization is very important in the conditions of fast technological development, particularly in the area of telecommunications and informatics, which enabled an important change in industry. The concept of a successful company with a single employee is business reality today, and these companies exist successfully among big companies with hundreds and thousands of employees, since, due to the mentioned technologies the individuals can have easier access to the market, as well as networking with similar companies, which means also successful business operation

A company with a single employee can meet today all its needs by outsourcing the services or products of other networked companies, which enables their business efficiency. Higher speed and flexibility of operation of such companies has brought a challenge: a large number of small companies have created a large number of small orders that need to be delivered within the same time unit. The logistics and distribution centres can be a solution which retains the speed and efficiency, and avoids costs of congestions and delays.

Croatia is yet building up its financial power and infrastructure in order to enter the competition with the leading countries in high-tech development. However, the territory of Croatia can be more efficiently used by concentrating the companies that develop high technologies. In order to prevent cheap "export" of brains into the developed countries, it is necessary to offer the international corporations these premises, as well as national professionals. It is necessary to offer to foreign corporations favourable conditions for the accommodation of the development companies or their parts (laboratories, institutes) in Croatia, and to connect them with the national or neighbouring research centres. One of the factors of economic development of Croatia lies in the establishment and operation of the technological parks and logistics distribution centres on the Croatian territory.

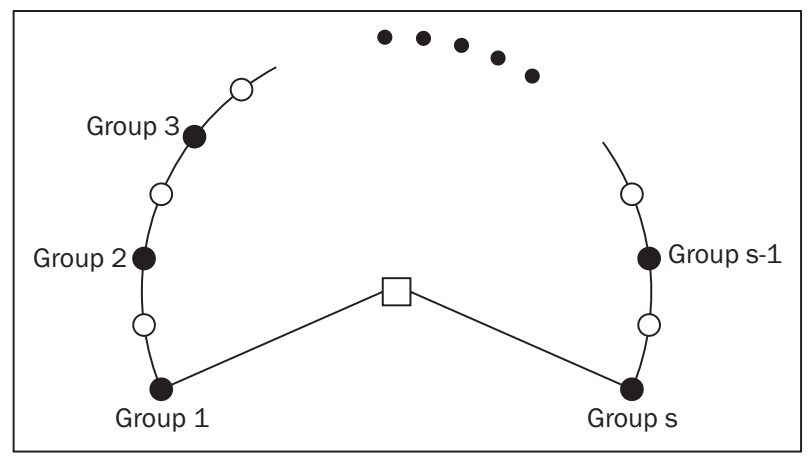

Figure 3 - Logistics and distribution network with logistics-distribution centres

Source: Simchi-Levi, D., Chen X. And Bramel J.,

The Logic of Logistics, p. 219 


\section{CONCLUSION}

Logistics, traditionally "relying" on urban road traffic, is one of the sources of continuous and sustainable increase of efficiency of companies and networks in urban areas, but logistics defined by the development of technology and its implementation in practice (especially in telecommunications and informatics) requires connections between technological parks in city suburbs with companies that find their markets in urban areas.

It may also be claimed that the structure of this paper has given also a concept of research that needs to be carried out in order to identify the integrity of relevant aspects of urban transport logistics in the process of technological development in post-socialism (and consequently - in Croatia as well), in order to identify the fulcral points and lever processes of creating and functioning of successful companies and the society in general.

In this sense we are only at the beginning, although the level of pressure which requires both urgent and long-term answers is increasing more and more. However, this has also identified a clear advantage: the tendency of complexity and dynamism of post-socialist transition processes towards change in the total structure both of the economy and its mechanisms is such that (along with resistances) they significantly change and raise the level of necessity and readiness for technological changes.

\section{Dr. sc. SAŠA PETAR}

E-mail: sasa@sasapetar.com

Status Prosper d.o.o.

Šamačka 41, 10000 Zagreb, Hrvatska

IVONA BAJOR, dipl. ing.

E-mail: ivona.bajor@fpz.hr

SINIŠA RADULOVIĆ, dipl. ing.

E-mail: sinisa.radulovic@fpz.hr

Sveučilište u Zagrebu, Fakultet prometnih znanosti

Vukelićeva 4, 10000 Zagreb, Hrvatska

\section{SAŽETAK}

\section{TRANSFER TEHNOLOGIJE I LOGISTIČKO- DISTRIBUCIJSKI CENTRI}

Transfer kapitala i tehnologija u određenu regiju dovodi i do povećanih zahtjeva za logističkim uslugama. Prijelaz na organizaciju logističke dostave vrlo je važan u uvjetima ubrzanog tehnološkog razvoja, osobito u području telekomunikacija i informatike, koji je omogućio pojavu uspješnih tvrtke s jednim zaposlenim. Zahvaljujući navedenim tehnologijama ove tvrtke umrežavaju se sa sličnim tvrtkama, pa tako mogu sve svoje potrebe riješiti outsourcingom usluga ili proizvoda drugih umreženih tvrtki. Veća brzina i fleksibilnost poslovanja takvih tvrtki donijela je izazov: veliki broj malih tvrtki stvorio je veliki broj malih narudžbi koje je potrebno dostaviti u istoj jedinici vremena. Logističko-distribucijski centri mogu biti rješenje kojim se zadržava brzina i efikasnost, a izbjega- vaju troškovi zagušenja i kašnjenja.

\section{KLUUČNE RIJEČI}

transfer kapitala, transfer tehnologije, logističko-distribucijski centri, optimizacija

\section{REFERENCES:}

1. Growing champignons in abandoned railway tunnels and tennis courts in old port warehouses are exceptions that confirm the rule.

2. www.poslovni-park.hr

3. www.kingsturge.hr

\section{LITERATURE}

[1] Allen, J.C.: Starting a Technology Business, Pitman Professional Publishing and NatWest Technology Unit, London, 1992

[2] Breheny, Michael J. and Ronald McQueid: The Development of High Technology Industries - An International Survey, Academic Press, New York, 1987

[3] Brotchie, John F., Peter Hall and Peter W. Newton: The Spatial Impact of Technological Change, Academic Press, New York, 1987

[4] Fujita, M. and Thisse, J-F.: Economics of Agglomeration, Cambridge University Press, Cambridge, 2002

[5] Fujita, M., Krugman P. and Venables, A.J.: The Spatial Economy, The MIT Press, Cambridge (Mass, USA), 2001

[6] Habersam, M.: Technology Centre Networks and Regional Development, Witten / Herdecke University, Witten, 1994

[7] Massey, Doreen, Paul Quintas and Daniel Wield: High Tech Fantasies - Science Parks in Society, in Science and Space, Rutledge, London / New York, 1992

[8] Petar, mr S.: Location Conditions for Technology Transfer; in International Conference "Investment Strategies and Management of Construction", in Society of Croatian Construction Managers, Brijuni/Zagreb, 1994

[9] Petar, mr S.: Situation, Challenges and Problems of Croatian Enterprises and the Role for Industrial Innovations; in Lange, Siegfried and Jadranka Švarc (ed.) "Conceptual Approaches for an Industry-Related Promotion of Research and Development in Croatia: Workshop Proceedings, Fraunhofer-Institut für Systemtechnik und Innovationsforschung (ISI), Jülich, 1995

[10] Petar, S.: Tehnološki parkovi - infrastrukturni okvir transfera tehnologije; in Plenković, Prof. dr. sc. Juraj (ed.), "Društvo i tehnologija 95" (Society and Technology 95), Faculty of Civil Engineering University of Rijeka, Opatija, 1995

[11] Salamon, D. and Petar S. (ed.): Tehnološki centri $i$ poslovni i inovacijski centri u Hrvatskoj - perspektive razvoja, (Technological centres and business and innovation centres in Croatia - development prospects) Croatian Chamber of Economy, Zagreb, 1995

[12] Sigurdson, J.: Measuring the Dynamics of Technological Change, London / New York, 1990

[13] Soja, E.W.: Postmetropolis, Blackwell Publishing, Oxford, 2000 
[14] Thwaites, A.T. and Oakey, R.P.: The Regional Economic Impact of Technological Change, Penguin Books, Harmondsworth, 1985
[15] Županović, I.: Tehnologija cestovnog prijevoza, (Road Transport Technology), Faculty of Transport and Traffic Sciences, Zagreb, 2002 